\title{
Türkiye'de Defne (Laurus nobilis L.) Bitkisinin Durumu
}

\author{
Abdurrahim Yilmaz ${ }^{1 *}$, Vahdettin Çiftçi \\ 1* Bolu Abant İzzet Baysal Üniversitesi, Ziraat Fakültesi, Tarla Bitkileri Bölümü, Bolu, Türkiye, (ORCID: 0000-0001-9991-1792), ayilmaz88@ hotmail.com \\ ${ }^{2}$ Bolu Abant İzzet Baysal Üniversitesi, Ziraat Fakültesi, Tarla Bitkileri Bölümü, Bolu, Türkiye (ORCID: 0000-0002-0440-5959), vahdet2565@ yahoo.com
}

(İlk Geliş Tarihi Aralık 2020 ve Kabul Tarihi Ocak 2021)

(DOI: $10.31590 /$ ejosat.856195)

ATIF/REFERENCE: Yılmaz, A. \& Çiftçi, V. (2021). Türkiye'de Defne (Laurus nobilis L.) Bitkisinin Durumu. Avrupa Bilim ve Teknoloji Dergisi, (22), 325-330.

$\ddot{O} \mathbf{z}$

Ülkemizin önde gelen uçucu yağ ve aromatik bitkilerinden birisi olan defne (Laurus nobilis L.)'nin ekonomimizdeki yeri oldukça önemlidir. Yaprağından baharat, yağından sabun, parfüm ve vücut losyonu elde edilen defne bitkisi ilaç sanayinde de değerlendirilmektedir. Ayrıca tentür, çay yapımı ve aromaterapi amaçlı olarak da kullanılmaktadır. Antifungal ve antimikrobiyal özellikleri sayesinde gıda koruyucu olarak da değerlendirilen defne bitkisinin ülkemizde yaygın olarak kullanılmaktadır. Mide ve bağırsak gazlarını giderici, iştah açıcı ve idrar söktürücü özellikleri de bulunan bu bitki üzerine yapılan detaylı çalışmalar arttıkça değeri daha çok anlaşılmaktadır. Ancak çok yıllık bir bitki olmasından dolayı ıslah çalışmalarına yeterince zaman ayrılamamıştır. Bu sebeple geliştirilen bir çeşit henüz bulunmamaktadır. Son yıllardaki verilere göre dünya defne pazarının yaklaşı \% 90 'ına hâkim olan ülkemizde bu bitkinin potansiyeli daha iyi değerlendirilmeli ve araştırmacıların yönelimi artırılmalıdır. Bu vesile ile bu derleme, defne bitkisine yönelimin artmasını amaçlama niteliği taşıyarak bazı defne kalite parametrelerini, defne kullanım alanlarını, defne pazarını ve ekonomik değerini içermektedir.

Anahtar Kelimeler: Defne, Laurus nobilis L., Kullanım alanları, Ekonomik değer

\section{Status of Laurel Plant (Laurus nobilis L.) in Turkey}

\begin{abstract}
Laurel (Laurus nobilis L.), one of our country's leading essential oil and aromatic plants has very important place in our economy. The laurel plant, which has been producing spices from its leaves, soap, perfume and body lotion from its oil, is also used in the pharmaceutical industry. It is also used for tincture, tea making and aromatherapy. Laurel plant, which is also used as a food preservative thanks to its antifungal and antimicrobial properties, is widely used in our country. However, since it is a perennial plant, it hasn't been enough time for breeding works. For this reason, there is no standard variety developed yet. According to recent data, in our country, which dominates about $90 \%$ of the world Laurel market, the potential of this plant should be better evaluated and the orientation of researchers should increase. Hereby, this review contains some laurel quality parameters, bay usage areas, laurel market and economic value, aiming to increase the orientation to the laurel plant.
\end{abstract}

Keywords: Laurel, Laurus nobilis L., Usage areas, Economic value

\footnotetext{
"Sorumlu Yazar: ayilmaz88@hotmail.com
} 


\section{Giriş}

Tıbbi bitkiler, doğadan toplanan, kültürü yapılan ve drogu alınarak alternatif tıp sektöründe veya ilaç sanayinde kullanılan bitkilerdir. Aromatik bitkiler ise aroma ve koku özelliği bulunan bitkilere denilmektedir (Sezik, 2014). Her iki kelimenin de yer aldığı tıbbi ve aromatik bitkiler ise insan ve hayvan sağlı̆̆ının korunmasını sağlayan, hastalıkları önleyen, içerisinde etken maddeler bulunan ve iyileştirici etkilerinden yararlanılan bitkilerdir (Arslan, 2007). Tibbi ve aromatik bitkilerin önemi, insanların beslenme, sağlık ve kozmetik sektöründe doğaya ve doğal kaynaklara olan eğiliminden dolayı gün geçtikçe artmaktadır. Tibbi ve aromatik bitkilerin rutin yaşam koşullarındaki gerekliliği ve önemi hiçbir zaman azalmayacak ve akademik camiâ içerisindeki popülerliğini daima koruyacaktır. Okigbo ve ark. (2008)'na göre tıbbi ve aromatik bitkiler; özellikle son yıllarda kırsal kesimdeki insanların ekonomilerindeki rolleri, tıbbi uygulamalardaki kapsamları, kültürel konulardaki kullanımları ve sonuç olarak insanların refahlarına olan katkıları nedeniyle giderek daha fazla tanınmaktadır. Ticaret hacminin büyümesiyle ve oluşan talebin gün geçtikçe artmasıyla da söz konusu bitkilerin üretimine yönelik çalışmaların arttırılması giderek hız kazanmıştır. Netice itibariyle tıbbi ve aromatik bitkilerin doğada toplama oranlarında da ciddi artışlar meydana gelmiştir (Acıbuca ve Budak, 2018).

Ülkemizin önemli tıbbi ve aromatik bitkilerinden birisi olan defne bitkisi dünyada diğer tıbbi ve aromatik bitkilere kıyasla yaygın olarak tanınmamasına karşın Türkiye'de ekonomik değeri ve popülerliği yüksek olan bitkilerdendir. Defne (Laurus nobilis L.) bitkisi antik çağlardan beridir kullanılan ve değer verilen bir tıbbi ve aromatik bitki olup, ülkemiz ve diğer bazı dünya ülkeleri açısından da bu özelliğini halen korumaktadır (Kayacık, 1977; Bayan, 2016). Antik çağlarda olimpiyat müsabakalarında başarılı olan sporcuların alınlarına defne yapraklarından oluşturulan taç ile ödül verildiği bilinmektedir. Roma döneminde milattan önce 342 yılında altın paraların üzerinde defne bitkisinden çelenk figürü bulunduğu, Yunanlılar ve Romalıların spor ve savaş zaferlerinde bu bitkinin yapraklarından yapılan çelenkleri taç olarak kullandıkları, ayrıca eski Romalılar döneminde defne yaprağının yıldırım çarpmasına karşı insanları koruyucu etkide olduğuna inanıldığı ve firtınalı havalarda birer defne dalı bulundurdukları da bilinmektedir (Duke, 1987; Duke ve ark., 2008).

Defne bitkisinin anavatanı bazı kaynaklarda Akdeniz ülkeleri, bazı kaynaklarda ise Küçük Batı Asya (Anadolu) ve Balkanlar olarak geçmektedir. Lauraceae familyasında yaklaşık olarak 45 cins ve 1000 tür, Laurus cinsinde ise L. canariensis Willd ve Laurus nobilis L. olarak iki tür yer almaktadır. Bitkiler aleminde vasküler (Damarlı) bitkiler sınıfında yer alan defne bitkisi (Laurus nobilis L.), tohumlu bitkiler (Spermatophyta) şubesi, dikotiledonlar (Magnoliopsida) sınıfı, Magnoliidae alt sınıfi, kapalı tohumlular (Angiospermae) alt bölümü, Laurales takımı, defnegiller (Lauraceae) familyası ve Laurus cinsi içerisinde yer almaktadır. Laurus nobilis'in ise, kenarları dalgalı olan aurea, crispa ve undula ile dar yapraklı olan angustifolia olarak 4 alt türü bulunmaktadır (Kayacık, 1977; Seçmen ve ark., 1995; Baydar, 2009; Boza, 2011).

Eski çağlardan itibaren Akdeniz'deki tüm kıyı şeridinde görülen defne bitkisi, Türkiye en başta olmak üzere Yunanistan, Cezayir, Fas, Fransa, Belçika, Meksika, İspanya, Portekiz, Kanarya Adaları gibi ülkelerde de yayılış göstermektedir. Diğer e-ISSN: 2148-2683 yayılış alanları Libya, Romanya, Arnavutluk, Suriye, Kırım başta olmak üzere tüm diğer Batı Akdeniz Havzası'dır (Ayanoğlu ve ark., 2010). Dünyanın diğer ülkelerinde defne bitkisi İngilizcede; Laurel, Sweet Bay, Bay Laurel, İspanyolcada; laurel, Fransizcada; Laurier Sauce, Laurier, Almancada; Lorbeerbaum, Lorbeer, Çincede; Ye Gui, Japoncada; gekke iju, İtalyancada; Lauro, Alloro, Arapçada; Habbül Gar, Rend Gar, Rusçada; Laur Brogorodry, İsveçcede; lager, Fincede; Laakerinlehti, Laarkeripuu ve Lehçede; Wacurnzyn Szlachetny olarak isimlendirilir (Pala, 2010; Yurtlu, 2011).

Defne bitkisinin Türkiye'deki yayılışı ise Ege ve Akdeniz bölgesinin alçak rakımları ile Karadeniz bölgesinde Akdeniz iklimini temsil eden alanlardır. Bitkinin yaygın olarak görüldüğü iller Bursa, Balıkesir, Yalova, İstanbul, Kastamonu, Sinop, Zonguldak, Rize, Trabzon, Muğla, İzmir, Mersin, Antalya ve Kahramanmaraş'tır (Şekil 1; Davis, 1982; Şafak ve Okan, 2004).

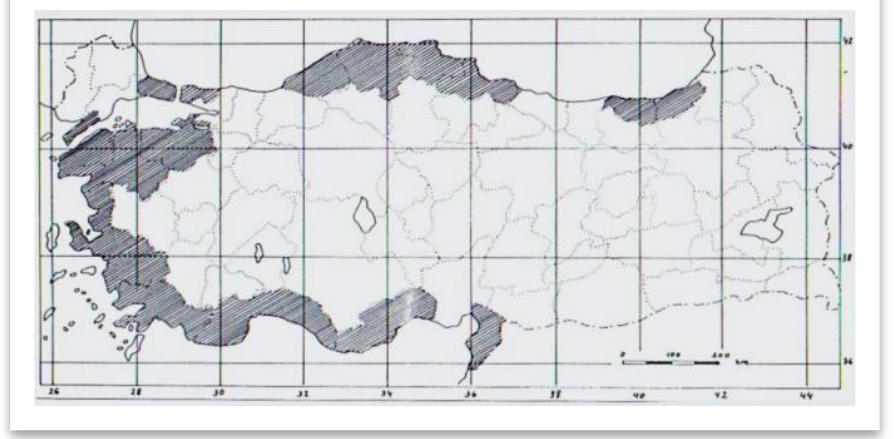

Şekil 1. Defnenin Türkiye'deki yayılış alanları (Davis, 1982)

Davis (1982)'in tanımlamalarına göre defne ağacı, yaprak dökmeyen, çalı tipi, 2,15 m uzunluğa kadar boylanabilen Akdeniz bölgesine özgü bir bitkidir. Amerika'da ve Avrupa'da süs bitkisi olarak yetiştirilen bu bitki, Türkiye'nin genellikle sahil şeridinde olmak üzere $600-800 \mathrm{~m}$ rakımlara kadar yetişebilmektedir. Defne bitkisi yağışı yeterli, nemli ve güneşli iklimlerde iyi gelişmektedir. Genç dönemlerde dona karşı hassas olan defne ağaçları tipik Akdeniz iklimine çok iyi adaptasyon sağlamıştır. Yazın sıcak ve nemli, kışın ise ılıman ve yağışlı iklim isteğine sahiptir. Yüksek rakımlarda yaprak alanı ve uçucu yağ içeriğgi azalmaktadır. Kültürü için de drenaj sorunu olmayan, süzek, hafif kireçli ve verimli topraklar tercih edilmelidir (Baydar, 2009). Defne bitkisinin yayılım alanlarına etki eden en önemli faktörler; toprak yapısı ve hava nemidir. Genellikle taban suyunun yüksek olduğu akarsu kenarı ya da denizden gelen nemli rüzgarlara hakim yüksekliklerde yetişebildiği görülmüştür. Doğal olarak yayılış gösterdiği alanlarda toprak yapısı balçık, balçıklı kum, kumlu balçık, killi balçık, kil ve kumlu killi balçık halinde orta derin topraklar olup ana kayası kalkerdir. Defne bitkisinin yetiştiği alanlarda topraklar tuzsuzdur ve tuzluluk problemine rastlanmamaktadır. (Güler, 2006; Özel ve ark., 2008; Parlak ve Demirci, 2011; Düzenli ve Karaömerlioğlu, 2012; Baytöre, 2014).

Ana yayılış bölgesi Balkanlar, Küçük Asya ve Akdeniz Havzası olan defne (Laurus nobilis L.), makinin (Akdeniz bitki örtüsü) tipik ağaçlarındandır ve genellikle batı ile kuzey yamaçlarda, dere ve serin vadi içlerindeki nemli alanlarda ve Pinus brutia'nın (Kızılçam) bulunmadığı açık bölgelerde yayılış göstermektedir. Kurak ve sıcak alanlarda ise daha az görülmektedir. Bitki bu alanlarda 7-8 m'ye kadar boylanabilmektedir. Karadeniz Bölgesi'nde ise yalancı makiden (pseudomaki) dolayı denizin hemen kıyısında yer alan defneler, 
bu bölgenin 0 m'den başlayıp $100 \mathrm{~m}$ ve biraz üzeri rakımlara kadar olduğu alanlarında yetişebildiği görülmektedir (Güler, 2006; Düzenli ve Karaömerlioğlu, 2012).

Türkiye, Meksika, Portekiz, İtalya, İspanya, Fransa, Cezayir ve Fas'taki defne bitkisinin aromatik yaprakları ticari amaçlar için yetiştirilmektedir. Türkiye, dünyada en büyük ihracatçı ülke konumundadır. $\mathrm{Bu}$ nedenle, Türkiye'nin en popüler şifalı ve aromatik bitkilerinden olan defne bitkisi, birçok amaç için yetiştirilmektedir. Defne yaprakları genellikle Türkiye'de balık, et, çorba, güveç, puding, sirke ve içecekler için baharat ve aromatik tatlandırıcılar olarak kullanılmaktadır. Bir diğer yetiştirme amacı uçucu yağ üretimi olan defnenin uçucu yağının az miktarda da ihracatı yapılmaktadır. Hem uçucu yağı hem de sabit yă̆ı; gıda, kozmetik ve tıbbi amaçlar için kullanılmaktadır. Defne yaprakları ayrıca halk tıbbında romatizma, gastrointestinal problemler ve idrarla ilgili problemlerin tedavisinde de yaygin olarak kullanılmaktadır (Ali-Shtayeh ve ark., 2000). Defne yapraklarında antioksidan, antiseptik, antibakteriyel, antienflamatuar, antikonvulsant, antifungal, ağrı kesici, terletici, migren önleyici, mide rahatsızlıklarını giderici ve diyabeti tedavi edici özellikler bulunmaktadır. Ayrıca defne bitkisinin halsizlik, hazımsızlık, uykusuzluk, aybaşı düzensizlikleri ve romatizma hastalıklarına da iyi geldiği birçok araştırmada ortaya konmuştur (Baytop, 1984; Acartürk, 1997; Duke, 1997; Özhatay ve ark., 1997; Sayyah ve ark., 2002; Sayyah ve ark., 2003; Simic ve ark. 2003; Rodilla ve ark., 2008). Sentetik boyar maddelerin yerine son zamanlarda doğal boyar maddelere olan ilgi giderek artmaktadır. Meyvesinde bulunan antosiyanin içeriği ile defne bitkisi (Laurus nobilis L.); kozmetik, ilaç ve gıda sanayinde doğal boyar madde olarak da değerlendirilmektedir (Özer, 1987; Hammer ve ark., 1999; Driver ve Arroy, 2001; Longo ve Vasapollo, 2005).

\section{2. Ülkemizde Defne Bitkisi}

Halk arasında defne (Laurus nobilis L.) bitkisi pek çok farklı isimle adlandırılmaktadır. Mersin, Osmaniye ve Adana'da "teynel, har, defne", Hatay'da "gar, teynel, har ve defne", Manavgat, Antalya-Gazipaşa, Akseki, Finike, Sırt Köy ve Sinanhoca Köyü’nde "ehnel”, Kahramanmaraş'da "harve, defne", Sakarya'da ve Samsun Alaçam'da "taflan, defne", Kastamonu İnebolu'da "defnün" ya da "tefrin" (meyve vermeyen defnelere "aşlı", veren defnelere "açtı" ismi verilmekte), Bartın'da "tehni", Cide'de "talimi" gibi farklı yöresel isimler verilmekte ve Güzelbağ'da defne tohumuna "gilik" denilmektedir. Diğer bazı yerlerde ise "tehnel, tenel, nehtel, tefrün, tahnal ve teynel" isimleri kullanılmaktadır (Baytop, 1994; Düzenli ve Karaömerlioğlu, 2012; Baytöre, 2014).

Türkiye'de hem iç pazarda bulunan hem de ihracata yönelik olarak toplanan defne türü, Akdeniz defnesi olarak bilinen Lauris nobilis'tir. Akdeniz defnesi defnegiller familyasından her mevsim yeşil renkte kalabilen yaprakları olan, hoş kokulu ve kullanım alanı oldukça geniş olan bir çalı türüdür. Türkiye'nin sahip olduğu defne envanteri $298.948 .953 \mathrm{~kg}$ 'dır ve bu veri ile dünya defne ihtiyacının yaklaşı olarak \%90's temin edilmektedir. Türkiye'de, alan olarak en yüksek defne yayılımına sahip iller sırası ile Adana, Muğla, Mersin, Bursa ve Kahramanmaraş'tır. Dış ticaret rakamlarına bakıldığında, defne ihracatı toplamının 2005 yılından itibaren 2015 yılına kadar yaklaşı olarak 3 katına çıktığı görülmüştür. 2015 verilerinde
Adana'nın 22.239, Muğla'nın 15.796, Mersin'in 15.581, Bursa'nın 15.396 ve Kahramanmaraş'ın 13.893 hektarlık defne alanına sahip olduğu bilinmektedir (Şekil 2; OGM, 2016).

Türkiye'de defne bitkisinin en çok yetiştĭg 4 coğrafi bölgedeki (Karadeniz, Marmara, Ege ve Akdeniz) 100 lokasyondan temin edilen örneklerle uçucu yağ oranı ve bileşenlerini araştırmak için yürütülen bir çalışmada uçucu yağ oranları $\% 0,4-4,5$ arasında olup ortalama uçucu yağ oranı $\% 1,78$ olarak belirlenmiştir. Uçucu yağ bileşenleri ise 1,8 -cineole $(\% 31,87-67,56), \alpha$-terpinyl acetate $(\% 4,09-22,22), \alpha$-terpineol $(\% 0,94-16,08)$, linalool $(\% 0,40-13,04)$, terpinen-4-ol $(\% 2,31$ $9,22)$ ve sabinene $(\% 0,56-9,08)$ olarak tespit edilmiştir (Karı ve ark., 2015). Gen havuzu daha dar ölçekli olduğu Hatay'ın farklı lokasyonlarından defne uçucu yağı kimyasal içeriğinin karşılaş̧ırıldığı bir diğer çalışmada sırasıyla 1,8- cineole $(\% 46,61-59,94), \alpha$-terpinyl acetate $(\% 11,94-25,70), \alpha$-pinene $(\% 3,66-2,61)$ sabinene $(\% 14,05-7,83)$, terpinen-4-ol $(\% 1,82-$ 2,20) içerikleri belirlenmiştir (Sangun ve ark., 2007). Hasat esnası ve sonrasındaki kriterlerden; bitkinin gelişim döneminin, hasat saatinin, bitkinin bulunduğu bölgenin iklim koşullarının, bitkinin yöneyinin farklı olmasına bağlı olarak etkili madde miktarında meydana gelen bazı varyabiliteler oluşabilecektir. $\mathrm{Bu}$ sebeple, istenilen düzeyde etkili madde miktarlarını elde etmek için yürütülecek çalışmalarda tüm bu kriterler üzerine mümkün mertebe optimal koşulların sağlanması gerekmektedir.

Defne ağaçları ülkemizde devlete ait ormanlarda bulunduğu gibi özel mülkiyetler içerisinde de yer almaktadır. Orman alanlarında bulunan defne ağaçlarının meyve ve yapraklarının toplanması için Tarım ve Orman Bakanlı̆̆ı'ndan izin almak gerekmektedir. Defne yapraklarının üretimi için, Orman Genel Müdürlüğü'nün 283 sayılı tebliğ esasına ve yıllık üretim programına göre düzenlenme yapılmaktadır. 6831 sayılı Orman Kanunu'nun 37. maddesine göre izinler verilmekte ve sadece tarife bedeli alınarak 40. maddede ifade edilen köylerde üretim yaptırılmaktadır. Üreticileri teşvik amaçlı çok düşük tutulan bu bedel OGM (Orman Genel Müdürlüğ̈̈) tarafından belirlenmektedir. Defne'de yaprak üretimi, sahaya göre değişmekte ve amenajman planlarına bağlı sahalarda belirlenen plana göre yapılmaktadır. Üretim planı yapılmamış ise üretime dayalı sahalarda envanter çalışması yaparak seri planlama ya da yeterli potansiyel mevcut değil ise işletme bazında planlama yapılmaktadır. Ülkemizde yaprak üretimi haziran ayının ortasında ve temmuz ayı başlarında başlayıp ekim ayı sonunda bitmektedir. Bölgesel farklılıklara göre bu üretim zamanları mikro iklim kıyasına bağlı olarak değişim göstermektedir. Yalova'da Tarım ve Orman Kalkınma Kooperatifleri kapsamında yürütülen toplama işlemi, ekim ayında başlamakta ve tüccarlara yaş yapraklı olarak satışı yapılmaktadır (Yazıcı, 2002; Sivrikaya ve ark., 2006; Baytöre, 2014). Dünya'daki defne bitkisi varlığının \%90'ı ülkemizde bulunmakta ve yaklaşık olarak 150 bin ha alanda yayılış göstermektedir. Her yıl 22 bin ton civarı kurutulan defne yaprağı üretilmekte ve yaklaşık olarak 1 milyon insan da bu alanda istihdam etmektedir (OGM, 2017). 


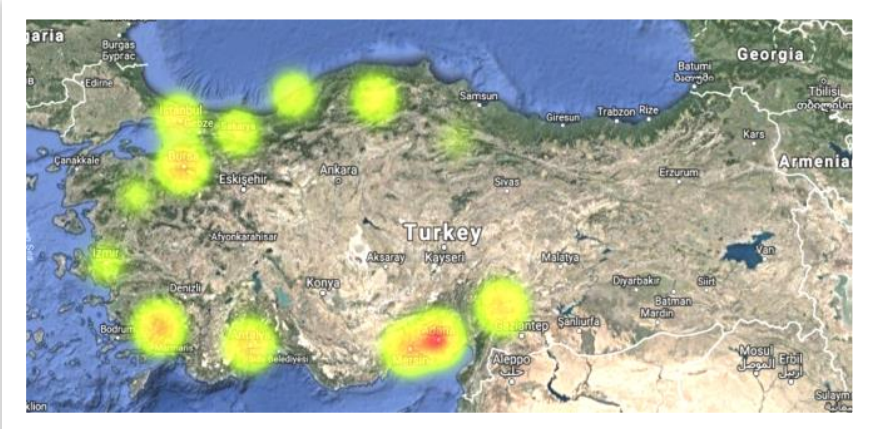

Şekil 2. Illere göre defne alanı haritası (OGM, 2016)

Defne bitkisi, büyük oranda orman arazilerinden orman köylüleri tarafindan, az oranda da özel arazi müteşebbisleri tarafindan toplanmaktadır. Arazi sahipleri defnenin meyve ve yapraklarını toplamak adına herhangi bir izin almamaktadır. Ancak kendi bölgelerindeki Orman İşletme Müdürlükleri'ne kendilerine ait olan araziden defne toplayacaklarına dair dilekçe vermeleri gerekmektedir (OGM, 2016).

Defne envanteri olarak Zonguldak'ın en yüksek envantere sahip il olduğu görülmektedir. Zonguldak, $101.288 .917 \mathrm{~kg}$ ile 298.948.953 kg'llk toplam Türkiye defne envanterinin 3'te 1 'inden fazlasina sahiptir. Sirasi ile defne envanterlerinde Zonguldak'1 Bursa (53.492.019), Mersin (34.379.228), Adana (26.309.022) ve Kahramanmaraş (22.430.933) illeri izlemektedir (Şekil 3; OGM, 2016).

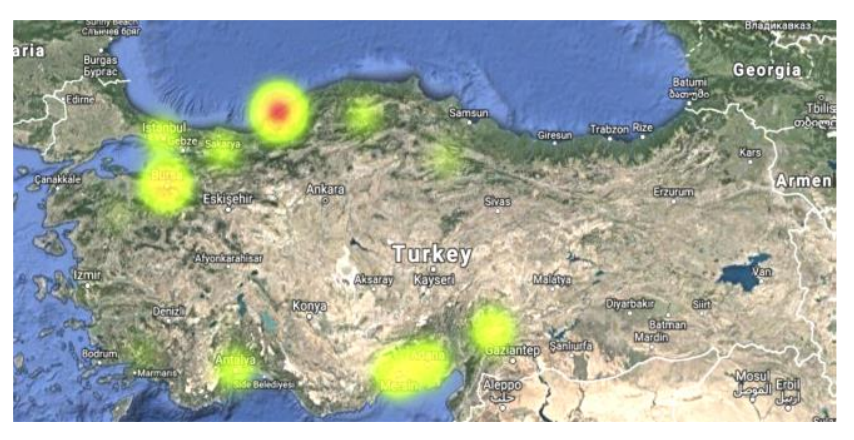

Şekil 3. İllere göre defne miktarı haritası (OGM, 2016)

Yıllara göre değerlendirildiğinde, Türkiye'de 2010 sonrası defne miktarının öncesine göre 3 kat arttı̆̆ görülmüştür. Gerek bölgedeki değişken faktörlerin defnenin ekonomik değerini görmesi, gerekse dünyada defne bitkisine olan talebin artması, tedarik süreçlerinin hızlandırılmasına ve defne bölgelerinde yeni aktörlerin ortaya çıkmasına neden olmuştur. Artış eğilimi bugün itibari ile de devam etmektedir: 2017 y1lında defne miktarı 30 bin tona yaklaşmışıı (Şekil 4; OGM, 2016; OGM, 2017a).

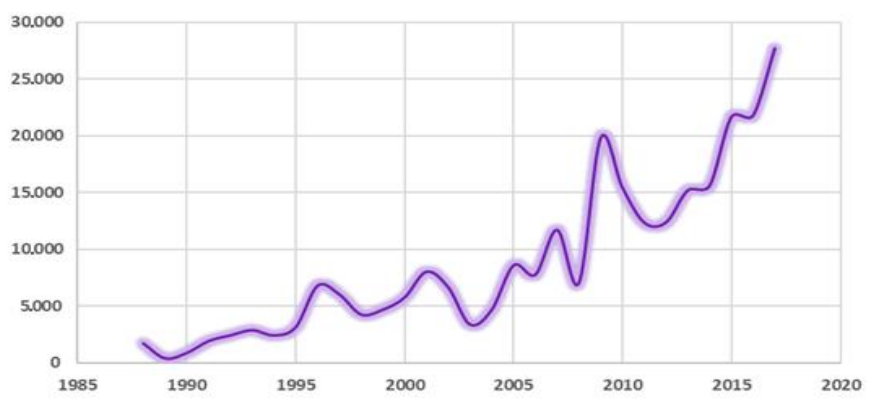

Şekil 4. Yıllara göre defne üretim miktarı (ton) (OGM, 2017a)
Dış ticaret rakamlarına bakıldığında da defne ihracatı toplamının 2005 yılından itibaren 2017 yllına kadar 3 kattan fazla arttığı ve 2017 itibarı ile kuru defne ihracatında 40 milyon dolarlık rakamlara yaklaşıldığı görülmüştür (36.058.749 \$). İhracatı yapılan yan ürünler de eklendiğinde defnenin ekonomik hacminin 100 milyon doların üzerinde olduğu tahmin edilmektedir (Şekil 5; OGM, 2016a; OGM, 2017b).

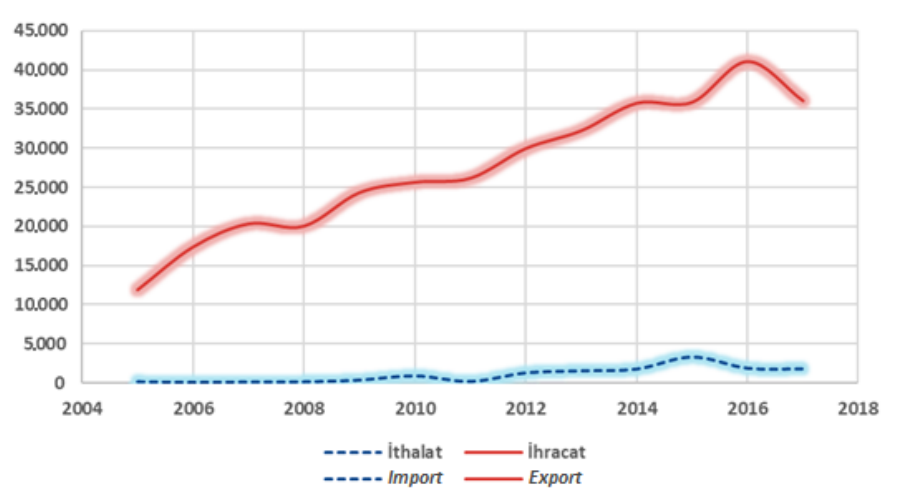

Şekil 5. Yıllara göre defne ithalat ve ihracatı (1000 \$) (OGM, 2017b)

Defne'nin değer değişimi üzerine değerlendirme yapıldığında ise; 2005 yllında 5.557 ton ihracatı yapılan defneden ton başına 2.130 dolar alındığ 1,2015 yılında ise 12.741 ton ihracatı yapılan defneden ton başına 2.817 dolar alındığı görülmüştür. 10 yıllık süreçte ihracatı yapılan defne miktarı iki katından fazlasına yükselmiş, ton başına satış bedelinde ise \%32'lik bir artış görülmüştür. Toplam olarak 2005 y1lından 2015 yllına kadar defne ihracat rakamlarının yaklaşık olarak 3 katına çıktığı görülmüştür (Çizelge 1; OGM, 2016).

Tablo 1. Defnenin ton başına değer değişimi (OGM, 2016).

\begin{tabular}{l|lll}
\hline Değer & $\mathbf{2 0 0 5}$ & $\mathbf{2 0 1 5}$ & Değişim \\
& & & \\
\hline Ton & 5557 & 12741 & $\% 32$ \\
& & & \\
\hline \$ & 11.838 .907 & 35.889 .541 & \\
\hline Ton başına \$ & 2130 & 2817 & \\
\hline
\end{tabular}

Defne miktarı ve ihracat rakamları birlikte değerlendirildiğinde 2017 yılı için defne miktarının 27.678 ton, ihracatının ise 12.708 ton olduğu görülmektedir. Hasat edilen defnelerin çok büyük bir bölümünün de ihraç edildiği görülmektedir. Ayrıca, yaş daldan ancak yaklaşık 5 'te 1 oranında ürün alınabildiği dikkate alındığında, kayıt altına alınamayan defne kesiminin söz konusu olabileceği anlaşılmaktadır. Envanter ve ihracat verilerine bakıldığında ise defnenin ihracat potansiyeli yüksek olduğu ve yan ürünlerinin çeşitliliği göz önünde bulundurulduğunda dünyada giderek daha fazla talep edilen bir ürün olacağı söylenebilir. 


\section{Sonuç}

Ülkemizin önemli uçucu yağ ve baharat bitkilerinden birisi olan defne bitkisi diş ticaretimizde önemli bir yere sahiptir. Defne bitkisi kültüre alınıp yetiştirilmediğinden dolayı doğadan toplanmaktadır. Ülkemizde aşırı toplama ve hatalı kültürel işlemler nedeniyle defne alanları tahrip olmaktadır. Defne gen kaynakları ıslah üzerine yapılan çalışmalarda yeterli düzeyde değerlendirilemediğinden, geliştirilen herhangi bir çeşit bulunmamaktadır. Ayrıca giderek artan taleplere karşı üretim miktarı da yeterli düzeyde değildir. Bu sebeple, ülkemizde defne genetik kaynakları yönünden mevcut zenginliğin yürütülecek olan çalışmalar ile ortaya çıkarılması ve bunların yeni çeşit geliştirme odaklı kullanılması oldukça önem taşımaktadır. Önceki çalışmalara bakıldığında defnenin genetik çeşitliliğine dair çalışmaların sayısı oldukça sınırlıdır. Geleceği tehdit altında olan defne bitkisinin korunması ve geliştirilmesi açısından yapılacak çalışmaların önemi gün geçtikçe artmaktadır. Bundan dolayı, ülkemizde defne ıslahı çalışmalarına ağırlık verilerek, yeni çeşitler geliştirilmesi ve bunların üretime katılarak ülkemiz defne üretiminin artırılması, acil olarak ele alınması gereken konulardandır. $\mathrm{Bu}$ gibi çalışmalara ağırlık verilmesi adına öncelikli olarak yerel defne genotiplerinin 1slah programlarındaki yeri ve öneminin çok iyi anlaşılması gerekmektedir. Bu sebeple, yerel defne genotiplerinin morfolojik ve moleküler düzeyde yeterli derecede tanımlanması ve bunların 1slah çalışmalarında kullanılması; farklı ekolojik bölgeler için defne çeşitlerinin elde edilmesine önemli katkılar sağlayacaktır.

Açıklama: Bu derleme, Bolu Abant İzzet Baysal Üniversitesi Fen Bilimleri Enstitüsü'nde yürütülen $\mathbf{6 2 0 8 2 5}$ numaralı doktora tezinin bir kısmını kapsamaktadır.

\section{Kaynakça}

Acartürk, R. (1997). Şifalı Bitkiler, Flora ve Sağlığımız. Ovak Yayınları, Yayın No:1, Ankara.

Acıbuca, V., Budak, D.B. (2018). Dünya'da ve Türkiye'de Tıbbi ve Aromatik Bitkilerin Yeri ve Önemi. Çukurova J. Agric. Food Sci. 33(1): 37-44.

Ali-Shtayeh, M.S., Yaniv, Z., \& Mahajna, J. (2000). Ethnobotanical survey in the Palestinian area: a classification of the healing potential of medicinal plants. Journal of Ethnopharmacology, 73(1-2), 221-232.

Arslan, N. (2007). Genel Tibbi Bitkiler Ders Notlar1 (Basılmamış kitap /Online), 2007.

Ayanoğlu, F., Mert, A., Kaya, A., \& Köse, E. (2010). Hatay Yöresinde Doğal Olarak Yetişen Defne (Laurus nobilis L.) Bitkisinin Kalite Özelliklerinin Belirlenmesi ve Seleksiyonu, Tübitak Proje No: 1080878, 268s, Hatay.

Ayanoğlu, F., Kaya, D.A., Mert, A., \& Köse, E. (2013). Determination of quality aspects and selection of native grown laurel (Laurus nobilis L.) in Hatay province of Turkey. 1st Mediterranean Symposium on Medicinal and Aromatic Plants (MESMAP-2013) 17-20 April 2013, Gazimagosa, Turkish Republic of Northern Cyprus. pp. 59.

Bayan AA (2016). International Engineering, Science and Education Conference, 22-26.

Baydar, H. (2009). Tibbi ve Aromatik Bitkiler Bilimi ve Teknolojisi. Süleyman Demirel Üniversitesi Ziraat Fakültesi Yayınları No. 51, Isparta, pp. 234-235.
Baytop, T. (1984). Türkiye'de Bitkiler ile Tedavi. İ.Ü., Eczacılık Fakültesi Yayınları No:40, İstanbul, pp. 520.

Baytop, T. (1994). Türkçe Bitki Adları Sözlüğü. Atatürk Kültür, Dil ve Tarih Yüksek Kurumu, Türk Dil Kurumu Yayınları, No: 578, Ankara.

Baytöre, F. (2014). Yalova ilinde farklı yüksekliklerde doğal olarak yetişen defne (Laurus nobilis L.) populasyonlarında bazı morfolojik ve kalite özellikleri ile ontogenetik varyabilitenin belirlenmesi. Namık Kemal Üniversitesi Fen Bilimleri Enstitüsü Tarla Bitkileri Anabilim Dalı, Tekridağ.

Boza, A. (2011). Karaburun Çeşme ve Dilek Yarımadası'nda Bulunan Doğal Defne (Laurus nobilis L.) Populasyonları Üzerinde Araştırmalar. Doktora Tezi, Ege Üniversitesi Fen Bilimleri Enstitüsü, Bahçe Bitkileri Anabilim Dalı, İzmir.

Davis, P.H. (1982). Flora of Turkey, Vol. 7, Edinburg Universty Pres, Edinburg, pp. 947.

Driver, C., \& Arroy, G. (2001). Contributions of Jeffrey Harborne and coworkers to the study of anthocyanins. Phytochemistry, 56, 229-236.

Duke, J.A. (1987). CRC Handbook of Medicinal Herbs, CRC Pres inc., Florida, pp. 677.

Duke, J.A. (1997). The green pharmacy: New discoveries in herbal remedies for common diseases and conditions from the world's foremost authority on healing herbs. NY: Rodale Press, New York, pp. 501.

Duke, J.A., Duke, P.A.K., Judith, L., \& DuCellie, J.L. (2008). Duke's Handbook of Medicinal Plants of the Bible CRC press, USA, pp. 237-240.

Düzenli, A. \& Karaömerlioğlu, D. (2012). Türkiyede Defne ve Defnecilik Orman ve Su İşleri Bakanlığ Müdürlüğü ISBN:978-605-4610-10-5, Ankara, pp. 5-8.

Güler, S. (2006). Defne (Laurus nobilis L.) Yaprağ1 Verimi Üzerinde Etkili Faktörlerin Belirlenmesi Üzerine Araştırmalar (Antalya-Manavgat Yaylaalan Örneği), Yüksek Lisans Tezi, Süleyman Demirel Üniversitesi Fen Bilimleri Enstitüsü Orman Mühendisliği Ana Bilim Dalı, Isparta.

Hammer, K.A., Carson, C.F., \& Rley, T.V. (1999). Antimicrobial Activity of Essential Oils and Other Plant Extracts. Journal of Applied Microbiology, 86, 985-990.

Karık, Ü., Çiçek, F., Tutar, M., \& Ayas, F. (2015). Türkiye defne (Laurus nobilis L.) populasyonlarının uçucu yă bileşenleri. Anadolu Ege Tarımsal Araştırma Enstitüsü Dergisi, 25(1), 1-16.

Kayacık, H. (1977). Orman ve Park ağaçlarının Özel sistematiği. Cilt II.

Longo, L., \& Vasapollo, G. (2005). Anthocyanins from Bay (Laurus nobilis L.) Berries. Journal of Agricultural and Food Chemistry, 53, 8063-8067.

O.G.M. (2016). Orman Genel Müdürlügüü, Odun D1ş1 Ürün ve Hizmetler Dairesi Başkanlığı, Defne Eylem Planı 20162020, Orman ve Su İşleri Bakanlığ1, Orman Genel Müdürlüğü $\quad$ Erişim: https://www.ogm.gov.tr/ ekutuphane/Yayinlar/ Defne_Eylem_Plani.pdf.

O.G.M (2017a). Ormancılık İstatistikleri, Tali Orman Ürünleri, Orman ve Su İşleri Bakanlığg, Orman Genel Müdürlüğü, 2017. Erişim: https://www.ogm.gov.tr/ekutuphane/Istatistikler.

O.G.M. (2017b). Orman Genel Müdürlüğü, Odun D1şı Orman Ürünleri Resmi İstatistikleri, 2017.

Okigbo, R.N., Eme, U.E., \& Ogbogu, S. (2008). Biodiversity and conservation of medicinal and aromatic plants in Africa. Biotechnology and Molecular Biology Reviews, 3(6), 127-134. 
Özel, N., Akbin, G., Öner, H.H.., Altun, N., \& Akbin, N.A. (2008). Batı Anadoluda Defne (Laurus nobilis L.) Yayılış Alanlarının Yetiştirme Ortamı Özelliklerinin Belirlenmesi Çevre ve Orman Bakanlığı Ege Ormancılık Araştırma Müdürlüğü Teknik Bülten No:40, Bakanlık Yayın No: 329, Müdürlük Yayın No: 39, İzmir, pp. 4-73.

Özer, S. (1987). Ülkemizdeki Bazı Önemli Orman Tali Ürünlerinin Teşhis ve Tanıtım Klavuzu. Orman Genel Müdürlüğü Yayını, Yayın No: 659, Seri No: 18, Ankara.

Özhatay, N., Koyuncu, M., Atay, S., \& Byfield, A. (1997). Türkiye'nin Doğal Tıbbi Bitkilerinin Ticareti Hakkında Bir Çalışma. Doğal Hayatı Koruma Derneği, ISBN:975-960819- 7, İstanbul pp. 121.

Pala, B. (2010). Defne (Laurus nobilis L.) Üzerinde Bazı Agroteknik Çalışmalar. Yüksek Lisans Tezi, Ege Üniversitesi Fen Bilimleri Ensitütüsü, İzmir.

Parlak, S., \& Demirci, A. (2011). Soil Properties in Natural Habitats of Daphne (Laurus nobilis L.) 2nd International Non-Wood Forest Products Symposium, Isparta, pp. 123.

Rodilla, J. M., Tinoco, M. T., Morais, J. C., Gimenez, C., Cabrera, R., Benito, D. M., Castillo, L., \& GonzalezColoma. A. (2008). Laurus novocanariensis essential oil: Seasonal variation and valorization Biochemical Systematics and Ecology, 36, 167-176.

Sangun, M.K., Aydın, E., Timur, M., Karadeniz, H., \& Çalışkan, M. (2007). Comparison of chemical composition of the essential oil of Laurus nobilis L. leaves and fruits from different regions of Hatay. Journal of Environmental Biology, 28(4) 731-733.

Sayyah, M., Valizadeh, J., \& Kamalinejad, M. (2002). Anticonvulsant activity of the leaf essential oil of Laurus nobilis against pentylenetetrazole- and maximal electroshock-induced seizures. Phytomedicine, 9, 212-216.
Sayyah, M., Saroukhani, G., Peirovi, A., Kamalinejad, \& M. (2003). Analgesic and anti-inflammatory activity of the leaf essential oil of Laurus nobilis Linn. Phytotherapy Research, 17, 733-736.

Simic M, Kundakovic T, \& Kovacevic N. (2004). Preliminary assay on the antioxidative activity of Laurus nobilis extracts. Fitoterapia, 74(6), 613-616.

Seçmen, Ö., Gemici, Y., Leblebici, E., Görk, G., \& Bekat, L. (1992). Tohumlu Bitkiler Sistematiği, Ege Üniversitesi Fen Fakültesi Kitaplar Serisi No. 116, İzmir, pp. 241.

Sezik, E. (2014). Tıbbi ve Aromatik Bitkiler ve Kalite”, İnönü Üniversitesi Tibbi ve Aromatik Bitkilerin Eczacılık ve Ormancılıktaki Önemi Çalıştayı.

Sivrikaya, F., Karahalil, U., Keleş, S., \& Kırış, R. (2006). Bazı Odun Dışı Orman Ürünlerinin (Reçine, Defne, Sığla) Amenajman Planlama Felsefesi Açısından Değerlendirilmesi, 1. Uluslararası Odun Dışı Orman Ürünleri Sempozyumu Bildiriler Kitabı, Trabzon, pp. 413424.

Şafak, İ., \& Okan, T. (2004). Kekik, defne ve çam fıstığının üretimi ve pazarlaması, Doğu Akdeniz Ormancılık Araştırma Müdürlüğü DOA Dergisi, 10, 101-129.

Yazıcı, H. (2002). Batı Karadeniz Bölgesinde Yetişen Defne (Laurus nobilis L.) Yaprak ve Meyvelerinden Faydalanma İmkanlarının Araştırılması. Doktora Tezi, Zonguldak Karaelmas Üniversitesi Fen Bilimleri Enstitüsü Orman Endüstri Mühendisliği Anabilim Dalı, Zonguldak.

Yurtlu, B.Y. (2011). Drying Characteristics of Bay Laurel (Laurus nobilis L.) Fruits in a Convective Hot-Air Dryer, African Journal of Biotechnology Vol. 10(47), 9593-9599. 